INTERNATIONAL JOURNAL OF SCIENTIFIC RESEARCH

\title{
KNOWLEDGE, ATTITUDE AND PRACTICE TOWARDS ORAL SUBMUCOUS FIBROSIS AND ITS ADJUVANT THERAPY
}

\begin{tabular}{|c|c|}
\hline \multicolumn{2}{|l|}{ Dental Science } \\
\hline Dr Manju J & Senior lecturer, Thai Moogambigai Dental College and Hospital, Chennai \\
\hline $\begin{array}{l}\text { Dr Mutum } \\
\text { Sangeeta Devi* }\end{array}$ & Senior lecturer, Madha Dental College and Hospital, Chennai *Corresponding Author \\
\hline Dr Rahul B & Senior lecturer, Thai Moogambigai Dental College and Hospital, Chennai \\
\hline $\begin{array}{l}\text { Dr Vasant M } \\
\text { Bhanushali } \\
\end{array}$ & Private Practitioner, Mumbai \\
\hline \multicolumn{2}{|r|}{ ABSTRACT } \\
\hline $\begin{array}{l}\text { Introduction: Oral Subm } \\
\text { areca nut and its products. } \\
\text { for treatment of osmf. M } \\
\text { preformed and distributed } \\
\text { osmf and the adjuvant the } \\
\text { widespread. Traditional } \mathrm{m}\end{array}$ & $\begin{array}{l}\text { ibrosis (OSMF) is a chronic progressive debilitating disease of oral cavity resulting from the habits like chewing } \\
\text { high risk of morbidity. The aim of the present study is to evaluate the awareness of osmf and its adjuvant therapy } \\
\text { and methods: It include } 100 \text { dentists from various parts of India and a questionnaire of } 10 \text { questions were } \\
\text { a. Response were collected and assessment has been done accordingly. Results: Most of the dentist are aware of } \\
\text { treating osmf. Conclusion: OSMF is mostly a disease of the Indian sub-continent, where chewing arecanut is } \\
\text { helps also often cure symptoms, but also eliminates root causes of illness. However, more research is still needed } \\
\text { cines and their efficacy and effectiveness in the treatment of oral diseases. }\end{array}$ \\
\hline
\end{tabular}

\section{KEYWORDS}

OSMF, adjuvant therapy, arecanut, curcumin, turmeric.

\begin{abstract}
Introduction
Oral Submucous Fibrosis (OSMF) has become a chronic progressive debilitating, high risk precancerous condition reported for the first time by Schwartz in 1952. He used the word 'atrophica idiopathica (tropica) mucosae oris'." ${ }^{[1]}$ It leads to increased epithelial fibrosis of the oral mucosa, oropharynx and occasionally, larynx, which gives rise to burning sensation and stiffness of the oral mucosa and sometimes leads to a continuous decrease in the opening of the mouth. Submucosa and deeper tissues might also be harmed in later stages of OSMF. The risk of its transformation into malignancy is found to vary from $7 \%$ to $30 \%{ }^{[2]}$
\end{abstract}

The etiopathogenesis of OSMF has not yet been fully understood, but areca nut has been detected as the main etiological factor of OSMF. Arecoline and tannin which is present in areca nut lead to excessive collagen synthesis and reduced breakdown. ${ }^{[3,4]}$ The most common early signs and symptoms includes burning sensation, dry mouth, blanching of mucosa and ulceration in oral cavity. The burning sensation presents while eating spicy food. ${ }^{[5]}$ Blanching of oral mucosa is induced by impaired local vascularity due to increased fibrosis and gives results of marble-like appearance. ${ }^{[6]}$ Blanching can be localized, diffuse or can be reticular.

There are various treatment modalities available including antioxidants, micronutrients, intralesional injections, corticosteroids, hyaluronidase, placental extracts, IFN- $\gamma$, physiotherapy and surgical including laser. ${ }^{[7]}$ In present scenario there are various adjuvant therapy available and many people are following adjuvant therapy for treating osmf.

Aim: The aim of the study is to evaluate the knowledge, attitude and practices of osmf and its adjuvant therapy for treatment of osmf among dental practitioners.

\section{Materials and Methods}

Study design and population:The present study included 100 dentists from various parts of India. All the dentist including both BDS and MDS with different speciality participated in the study.

Questionnaire:A pre-formulated questionnaire was prepared, consisting of 10 questions. [Table 1] Before starting the questionnaire demographic data were collected (qualification, gender, experience). The questionnaire was designed on the basis of the language of the respondent. The questions were designed to assess the knowledge, attitude, and practices of osmf and its adjuvant therapy in treating oral submucous fibrosis. In order to reduce the induced error, no time limit was given on the participants. Data was then recorded and tabulated in

\section{excel sheets for assessment.}

\section{Statistical analysis}

All data were tabulated and examined using the Statistical Package for Social Sciences Version 26.0 (SPSS software). Results on categorical data were given as frequency distribution.

\section{Result}

Dentists from various part of India were selected for the study. A total of 100 dentists responded positively and participated in the present study. The response in the present study stated that Qualifications responded $55 \%$ of them were MDS and $45 \%$ of them were BDS (fig. 1) out of which $46 \%$ were male and $54 \%$ were female (fig. 2). Experience of the participants were also recorded which shows 1-5 years (57\%), 610 years (17\%), $11 \&$ above years (14\%) and freshers (12\%) (Fig. 3).

Table 1: Questionnaire and response of participants

\begin{tabular}{|l|l|}
\hline Questions & Frequency \\
\hline Q1: Oral submucous fibrosis is a & \\
\hline A. Premalignant lesion & 17 \\
\hline B. Premalignant condition & 79 \\
\hline C. Carcinoma & 02 \\
\hline D. All of above & 02 \\
\hline $\begin{array}{l}\text { Q2: What is the most etiological factor causing } \\
\text { osmf? }\end{array}$ & \\
\hline A. Genetic susceptibility & 03 \\
\hline B. Nutritional factor & 04 \\
\hline C. Consumption of chillies & 04 \\
\hline D. Areca nut & 89 \\
\hline Q3: What are the symptoms of osmf? & \\
\hline A. Burning sensation & 08 \\
\hline B. Inability to open mouth & 10 \\
\hline C. Dysphagia & 01 \\
\hline D. All of above & 81 \\
\hline Q4 How frequent you see osmf case in your & \\
practice? & 06 \\
\hline A. Everyday & 37 \\
\hline B. Once in a week & 26 \\
\hline C. Once in a month & 31 \\
\hline D. Rarely & 09 \\
\hline Q5: What is the treatment of osmf? & 83 \\
\hline A. Medication (topical and systemic) & 1 \\
\hline B. Intralesional injection & \\
\hline C. Surgical & \\
\hline D. All of above & \\
\hline
\end{tabular}

. All of above 


\begin{tabular}{|l|l|}
\hline $\begin{array}{l}\text { Q6: What is your preferred treatment of choice of at } \\
\text { first stage? }\end{array}$ & \\
\hline A. Habitual intervention and medication & 10 \\
\hline B. Habitual intervention and physiotherapy & 16 \\
\hline C. Habitual intervention and injection & 01 \\
\hline D. Surgical & \\
\hline Q7: Have you ever treated osmf patient? & \\
\hline A. Yes & 80 \\
\hline B. No & 20 \\
\hline Q8: What is the adjuvant therapy for osmf you are & \\
\hline aware of? & \\
\hline A. Curcumin & 37 \\
\hline B. Aloe vera & 19 \\
\hline C. Gingelly oil and turmeric & 27 \\
\hline D. Tulsi and turmeric & 17 \\
\hline Q9: Have you ever used adjuvant for your practice? & \\
\hline A. Yes & 60 \\
\hline B. No & 40 \\
\hline Q10: Do you have a follow up for your patients? & \\
\hline A. Yes & 76 \\
\hline B. No & 24 \\
\hline
\end{tabular}

Fig.1. Distribution of Qualifications

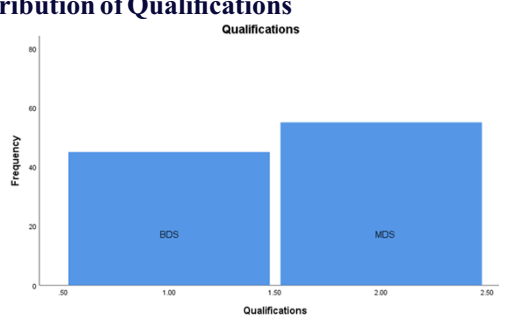

Fig.2. Gender distribution

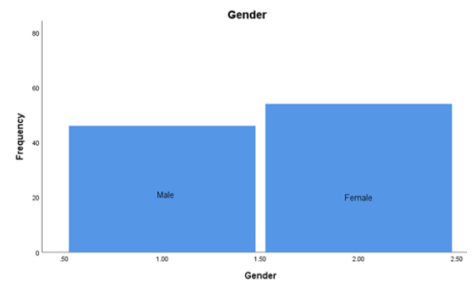

Fig.3. Distribution of experience

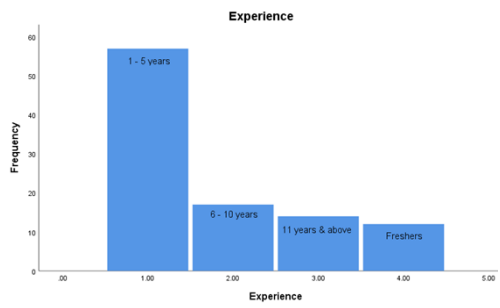

Most of the dentist were aware of what is osmf? Many (79\%) of them responded as premalignant condition. $17 \%$ responded as premalignant lesion. $2 \%$ responded as carcinoma and $2 \%$ of them responded as all of above.

Etiological factors of osmf $89 \%$ responded as arecanut, $4 \%$ as consumption of chillies, $4 \%$ nutritional factor and 3\% genetic susceptibility.

$81 \%$ of them were aware of sign and symptoms of osmf whereas others responded burning sensation $8 \%$, inability to open mouth $10 \%$ and dysphagia $1 \%$.

Frequency of seeing osmf in their practice, $37 \%$ dentist saw once in a weak, $31 \%$ saw rarely, $26 \%$ saw once in month and $6 \%$ saw every day.

For treating osmf cases $83 \%$ treated with all the available treatment, $7 \%$ treated with medication topical and systemic, $9 \%$ treated with intralesional injection and $1 \%$ treated surgically. For the preferred treatment of initial stage of osmf $73 \%$ did with habitual intervention and medication, $16 \%$ did with habitual intervention and injection, $10 \%$ did with habitual intervention and physiotherapy and $1 \%$ did surgical. $80 \%$ dentist has responded that they have treated osmf.

Adjuvant therapy awareness been asked in which $37 \%$ are aware of curcumin, $27 \%$ aware of gingelly and turmeric, $19 \%$ aloe vera and $17 \%$ Tulsi and turmeric. And about their practical usage of adjuvant therapy, $60 \%$ responded yes and also $76 \%$ of them has done follow-up for the cases.

\section{Discussion}

Despite the various current treatment methods used for OSMF, not a single treatment is completely effective in every case. Many pharmaceutical medicines have been shown to be successful in the treatment of OSMF and have also been found to have negative effects and recurrences. ${ }^{[8,9]}$ This research is to rule out the awareness of osmf and its adjuvant therapy for treating it.

Jha RN et al 2014 study revealed that arecanut is the main etiological factor causing osmf. ${ }^{[10]}$ In our study $89 \%$ has responded the same. Several factors have been involved as etiological factors, without excluding a single etiology, including the use of areca nuts, consumption of chilli, nutritional deficiency, genetic predisposition, autoimmunity and altered salivary composition.${ }^{[11]}$ In present study $3 \%$ responded as genetic susceptibility, $4 \%$ responded nutritional factor and $4 \%$ consumption of chillies. Babu et al also reported that gutkha consumption has main role which leads to OSMF. ${ }^{[12]}$

The signs and symptoms of OSMF reported according to Tupkar JV (2007), where burning symptom on eating hot and spicy food also restricted mouth opening were present in $97.02 \%$ patient. ${ }^{[13,14]}$ In our study $81 \%$ were aware of all the signs and symptoms like burning sensation, inability to open the mouth and dysphagia.

Yang analysed the prevalence, gender distribution, age, income, and urbanization status of OSMF patients which reported that OSMF has increased significantly from 8.3 in 1996 to 16.2 in $2013(\mathrm{P}<0.0001)^{[15]}$. In our study many dentists have responded of seeing osmf cases $37 \%$ once a weak, $26 \%$ once in month, $6 \%$ every day and $31 \%$ rarely which shows that osmf has increase in day to day practice.

Treatment modalities available for treating osmf are antioxidants, micronutrients, intralesional injections, corticosteroids, hyaluronidase, placental extracts, IFN- $\gamma$, physiotherapy and surgical including laser. ${ }^{[7]}$ In our study almost all $83 \%$ are aware of all the treatment modalities of osmf. Almost all the dentists have preferred the treatment according to the stage of the disease. $73 \%$ responded that for initial stage of osmf they preferred habitual intervention with medication (topical and systemic).

In our study $80 \%$ dentists has responded that they have treated osmf which shows that in present scenario osmf become common disease and almost all the dentists are aware of the disease. Apart from the treatment which is mentioned above, there are various adjuvant therapy for treating osmf.

Curcuma longa is commonly known for its anti-inflammatory and antioxidant action. In a study it was found curcumin and turmeric oil has significantly beneficial non-invasive herbal therapy for OSMF. Ram Sevak et al. Elaborated in his study, the anti-inflammatory, cytotoxic and antioxidant activity of curcumin I, II, III from Curcuma longa. ${ }^{[16,17]}$

Aloe vera has a very strong anti-inflammatory property. Sudarshan et al. reported that the use of aloe vera topically has found improvement in burning sensation and opening of the mouth as compared to antioxidant therapy. ${ }^{[18]}$

Turmeric is an anti-inflammatory agent which is used in traditional medicine, it has been shown that it suppresses the cellular transformation, proliferation of cells, invasion, angiogenesis, and also metastasis. ${ }^{[19]}$ Tulsi enhances the immunity and it improves metabolic functions also it has been found to reduce the inflammation by inhibiting enzymes. It also reduces the stress and has antioxidant properties. $^{[20,21,22]}$

The sesame plant has nutritional properties and many desirable health 
effects. The seeds are known as "gingelly" or "til" seeds. Sesame oil is a great source of vitamin $\mathrm{E}$ containing very high concentrations of polyunsaturated fatty acids and also antioxidants. ${ }^{[23]}$

Alam $\mathrm{S}$ et al conducted study which reported that the groups using aloe vera had a significant relief in most of the symptoms of OSMF $(\mathrm{P}<$ 0.01 ) when compared with the non-Aloe vera groups in both medicinal and surgical categories. According to Srivastava A etal 2015 study which shows statistically significant relieve in both burning sensation and mouth opening. Tulsi and turmeric has a safe and efficacious combination of natural products available for symptomatic treatment of OSMF. ${ }^{[22]}$

In our study $37 \%$ has responded curcumin, $19 \%$ responded aloe vera, $27 \%$ gingelly oil and turmeric and $17 \%$ responded Tulsi and turmeric for adjuvant therapy in treating osmf patients. In our study $60 \%$ of dentist already used adjuvant therapy. $76 \%$ were doing follow-up for the patient.

\section{Conclusion}

OSMF is mostly a disease of the Indian sub-continent, where chewing arecanut is widespread. Thus, there is an immediate need to initiate public health education measures to inform people about a debilitating, oral premalignant condition before it becomes too late. Traditional medicine also often helps to cure symptoms, and also eliminates root causes of the illness. However, more research is still needed on alternative and traditional medicines and their efficacy and effectiveness in the treatment of oral diseases.

\section{Financial support and sponsorship}

Nil.

\section{Conflicts of interest}

There are no conflicts of interest.

\section{Reference}

1. Schwartz J. Atrophia idiopathic atropica mucosa oris. In proceedings of the 11 th International Dental Congress in London. 1952. London. UK.

2. WollinaU, Verma SB, Ali FM, and Patil K. Oral submucous fibrosis: an update. Clin Cosmet Investig Dermatol. 2015;8: 193-204

3. Tilakarante WM, Klinikowski MF, Saku T, Peters TJ, Warnakulasuriya S, Oral submucous fibrosis: review on aetiology and pathogenesis. Oral Oncol. 2006; 42:561568 .

4. Rajalalitha P, Vali S. Molecular pathogenesis of oral submucous fibrosis- a collagen metabolic disorder J Oral Pathol Med 2005:2005:34:321-328

5. Auluck A, Rosin MP, Zhang L, Sumanth KN. Oral submucous fibrosis, a clinically benign but potentially malignant disease: Report of 3 cases and review of the literature. J Can Dent Assoc 2008; 74:735-40.

6. Chitturi RT, Kumar VA, Naik P, Kattimani V. Oral submucous fibrosis- An Indian perspective. Research 2014; 1:702.

7. Khan S, Sinha A, Kumar S, Iqbal H. Oral submucous fibrosis: Current concepts on aetiology and management-A review. Journal of Indian Academy of Oral Medicine and Radiog

8. Borle RM, Borle SR Management of oral submucous fibrosis: A conservative approach. Borle RM, Borle SR. Management of or

9. Scully C. The oral cavity. In: Champion RH, Burton IL, Ebling FJ, Editors. Textbook of Dermatology. 5th ed. London: Oxford Blackwell Scientific Publication; 1992. p. 2689-2760

10. Jha RN, Kalyani PB, Savarkar SV. Incidence rate of oral submucous fibrosis (OSMF) and its etiology in patients visiting Government Dental College and Hospital, Jamnagar (GDCH, Jamnagar). Journal of Integrated Health Sciences. 2014 Jan 1;2(1):11.

11. Ghom AG. Textbook of Oral Medicine. 2nd edition. Jaypee publications. p. 217-8

12. Babu S, Bhat RV, Kumar PU, Sesikaran B, Rao KV, Aruna P, et al. A comparative clinicopathological study of oral submucous fibrosis in habitual chewers of pan masala and betel quid. J Toxicol Clin Toxicol. 1996; 34:317-22

13. Tupkar JV, Bhavthankar JD, Mandale MS. Oral Submucous Fibrosis (OSMF): A study of 101 cases. JIAOMR. 2007;19(2):311-18

14. Yang SF, Wang YH, Su NY, Yu HC, Wei CY, Yu CH, et al. Changes in prevalence of precancerous oral submucous fibrosis from 1996 to 2013 in Taiwan: A nationwide population-based retrospective study. J Formos Med Assoc. 2018; 117:147-52.

15. Jain S, Shrivastava S, Nayak S, Sumbhate S. Recent trends in curcuma Longa Linn. Phcog Rev 2007; 1:119-28.

16. Das DA, Balan A, Sreelatha KT. Comparative study of the efficacy of curcumin and turmeric oil as chemo preventive agent in oral submucous fibrosis: A clinical and histopathological evaluation. J Indian Acad Oral Med Radiol2010;22:88-92.

17. Jiger V, Shashikant MC, Ali IM, Anshumalee N. Levamisole and antioxidants in the management of oral submucous fibrosis: Acomprative study. J Ind Acad Oral Med Radol2008; 20:135-40.

18. Sudarshan R, Annigeri RG, Vijaybala S. Aloe vera in the treatment for oral submucous fibrosis -Apreliminary study. J Oral Patol Med 2012; 41:755-6

19. Prakash P, Gupta N. Therapeutic uses of Ocimum sanctum linn (Tulsi) with a note on eugenol and its pharmacological actions: A short review. Indian J PhysiolPharmacol2005:49:12531.

20. Kelm MA, Nair MG, Strasburg GM, DeWitt DL. Antioxidant and cyclo oxygenase inhibitory phenolic compounds from Ocimum sanctum Linn. Phytomedicine 2000; 7:7 13.

21. Aggarwal BB, Prasad S, Reuter S, Kannappan R, Yadev VR, Park B, et al. Identification of novel anti inflammatory agents from ayurvedic medicine for prevention of chronic diseases: "Reverse pharmacology" and "bedside to bench" approach. Curr Drug Targets $2011 ; 12: 1595653$

22. Srivastava A, Agarwal R, Chaturvedi TP, Chandra A, Singh OP. Clinical evaluation of the role of tulsi and turmeric in the management of oral submucous fibrosis: A pilot, prospective observational study. Journal of Ayurveda and integrative medicine. 2015 Jan;6(1):45

23. Namiki M. The chemistry and physiological functions of sesame. Foods Rev Int 1995 11:281-329. 